\title{
EKUMENIESE WÊRELDDIAKONAAT EN WAT ONS DAARUIT KAN LEER
}

D CRAFFORD

\section{ABSTRACT}

Ecumenical word-wide diaconia and the lessons we can learn from it

Since 1948 the involvement of churches in ecumenical diaconia has become one of the most significant trends of modern church history. The most important agent of protestant christianity in this field is the Commission of Inter-Church Aid, Refugee and World Service of the World Council of Churches (CICARWS). A brief look at the history of CICARWS shows that a shift of emphasis took place from charity to justice, from individual to community and from development to revolutionary changes of social, political and economic structures.

The views of the Orthodox churches and Evangelical christians on world diaconia are to a certain extent a correction of the diaconal theory and practice of the World Council of Churches.

The Dutch Reformed Church in South Africa will have to consider the possibility of involvement in ecumenical diaconia very seriously and can learn many lessons from the history of world-wide diaconia since 1948.

As die geskiedenis van die kerk in die tydperk na d. weede Wêreldoorlog beskryf moet word, sal dit sonder twyfel bekend staan as die tydvak van die opbloei van ekumeniese diakonaat. Soos nooit tevore nie het die kerk bewus geword van die nood van die wêreld op talle terreine. Dit het sekerlik te doen met die feit dat die wêreld klein geword het as gevolg van moderne kommunikasiemiddele. Die radio, televisie en koerante dra daagliks die nood van die wêreld in mense se sitkamers in en dit maak gewetens wakker. Dit het egter ook te doen met die feit dat die kerk sy diakoniese roeping in die wêreld beter leer verstaan het. Daar is ingesien dat die sending van die kerk wat voortspruit uit die mission Christi nie net op die geestelike nood van die mens gerig kan wees nie, maar ook op sy materiële en sosiale nood.

Die konteks van die wêreld na 1948 met sy vele vorme van nood sowel as teologiese ontwikkelinge binne kerke het ' $n$ bydrae gelewer tot die geweldige opbloei van ekumeniese diakonaat.

Eers 'n kort woord oor die konteks. Die geweldige verwoesting wat die Tweede Wêreldoorlog in Europe veroorsaak het en die ontsettende lyding wat daaruit voortgespruit het, was die eerste faktor wat kerke uitgedaag het tot uitgebreide noodlenigingsprogramme. Daarna het die wêreldwye probleem van vlugtelinge die aandag getrek. Na die oorlog 
het die golf van dekolonisasie deur die wêreld getrek en die koloniale era is beëindig. Dit het die ontwikkelende lande wat nou vry was van koloniale beheer agtergelaat met talle ekonomiese en politieke probleme. Agteruitgang in die ekonomie en landbou het werkloosheid tot gevolg gehad. Dit, saam met ongekende droogtes het grootskaalse hongersnood veroorsaak. Op onderwysgebied en in mediese en gesondheidsdienste het die noodtoestand in talle gebiede krisisafmetings aangeneem. Daarby is die wêreld deur talle natuurrampe getref. In sulke omstandighede kon die kerke nie onaktief bly nie. In reaksie hierop het indiwiduele kerke en ekumeniese liggame 'n wêrelddiakonaat ontplooi wat jaarliks multi-miljoen rande bedra.

Wat teologiese ontwikkelinge betref, was daar ook heelwat wat die opbloei van kerklike diakonaat gestimuleer het. In die vyftigerjare is die kerk se taak in die wêreld beskryf met die terme kerugma, koinōnia en diakonia. ' $n$ Stroom van literatuur het verskyn waarin die begrip diakonia omskryf en met inhoud gevul is. Groot klem het geval op die diakoniese roeping van die kerk in lokale en mondiale verband. In navolging van die groot Diakonos moes die kerk ook 'n dienskneggestalte aanneem ${ }^{1}$ ' In dié fase is diakonia in hoofsaak gesien as barmhartigheid wat aan die wëreld moet geskied. Geleidelik het daar egter ' $n$ verskuiwing plaasgevind in die teologiese denke van barmhartigheid na geregtigheid. Daar is gevind dat agter die vele vorme van nood in die wêreld daar dikwels onregverdige sosiale, ekonomiese en politieke strukture is. In die sestigerjare het die klem dus weer grootliks geval op die kerk se sosiale getuienis teen onregverdige strukture. Daarna het 'n verdere verskuiwing plaasgevind van geregtigheid na bevryding. Hierin het die opkoms van die teologie van bevryding ' $n$ belangrike rol gespeel. Die primêre taak van die kerk is nou gesien as die bevryding van mense uit elke struktuur wat hulle verkneg en van menswaardigheid beroof. Dit sluit in bevryding uit armoede en onderontwikkeling, asook elke vorm van koloniale, sosiale of rasseoorheersing. Die laaste fase was die verskuiwing van bevryding na rewolusie. Toe geregtigheid en bevryding nie langs vreedsame weë en deur getuienis alleen bereik kon word nie, was die volgende stap om rewolusionêre verandering goed te praat. Die eerste stap in dié rigting het gekom by die Uppsala-vergadering van die Wêreldraad van Kerke waar revolusionêre verandering van sogenaamde onregverdige strukture in beginsel aanvaar is. In 1969 volg die stigting van die Program to combat racism (PCR) en daarna was daar groeiende steun van kerke aan bevrydingsbewegings in baie dele van die wêreld. Hierdie laaste ontwikkeling het die wêrelddiakonaat in 'n krisis gedompel. Oral het groepe in opstand gekom teen bestaande regerings met die argument dat hulle onderdruk word. Aangesien sogenaamde bevrydingsbewegings oral geweld en ter- 
rorisme as wapens gebruik, het die kerklike steun aan hulle 'n dilemma veroorsaak. Die diensknegte van die Vredevors moes nou kant kies tussen strydende partye en politieke faksies en moes selfs toesien hoe bewegings wat deur hulle gesteun is, die bloed van onskuldige mense vergiet. Die wêrelddiakonaat het dus drie duidelike fases deurloop. Eers het die klem geval op barmhartigheidsdienste in gevalle van akute nood. Daarna was dit ontwikkelingshulp aan agtergeblewe en ontwikkelende lande en tans val die klem op rewolusionêre verandering van onderdrukkende strukture.

Wêrelddiakonaat kan 'n denominasionele of 'n ekumeniese karakter aanneem. In die eerste geval word dit deur 'n enkele denominasie beoefen en in die laaste geval deur twee of meer kerke gesamentlik. Denominasionele diakonaat het dié voordeel bo ekumeniese diakonaat dat dit makliker aan plaaslike gemeentes verbind kan word, meer direkte persoonlike bande kan onderhou met diegene wat gehelp word, direk en vinnig hulp kan verleen, en dat dit nie lomp en duur strukture vir hulpverlening hoef op te rig nie. Dit het die nadeel dat die hulp wat verleen word nie so omvangryk kan wees as in die geval van ekumeniese wêrelddiakonaat nie.

As voorbeelde van kerke wat 'n eie wêrelddiakonaat ontplooi het, kan genoem word die Christian Reformed Church of America, die Gereformeerde kerke in Nederland en die Lutherse Kerke in Duitsland met hulle organisasies Brot für die Welt, Kirchlicher Entwick/ungsdienst en Dienste in Übersee.

In hierdie artikel wil ek egter die klem laat val op ekumeniese wêrelddiakonaat en op die lesse wat ons daaruit kan leer vir die SuidAfrikaanse situasie. Die mees omvangryke protestantse ekumeniese organisasie vir wêrelddiakonaat is die Commission on Interchurch Aid, Refugee and World Service (CICARWS) van die Wêreldraad van Kerke (WRK). Ons wil begin met 'n kort oorsig oor die wêrelddiakonaat van die WRK. Daarna wil ons kortliks kyk na die beskouing van Evangeliese Kerke en die Ortodokse Kerke oor die onderwerp. Ten slotte wil ons kyk na implikasies wat dit kan hê vir die NG Kerk se betrokkenheid by wêrelddiakonaat en na 'n aantal knelvrae wat ontstaan rondom wêrelddiakonaat.

\section{Wêrelddiakonaat van die WRK}

Die verhaal begin in 1942 toe die WRK, wat toe nog in 'n stadium van voorbereiding was, reeds 'n Department of Reconstruction and InterChurch Aid in die lewe geroep het. Die bedoeling was om hulp te verleen aan die duisende krygsgevangenes en vlugtelinge in Europa en om kerke 
wat swaar gely het in die oorlog weer te help met heropbou.

$\mathrm{Na}$ die amptelike stigting van die WRK te Amsterdam in 1948 is besef dat hulpverlening aan kerke en vlugtelinge ' $n$ permanente taak van dié organisasie sou wees. Daarvoor is voorsiening gemaak met die instelling van die Department for Inter-Church Aid and Service to Refugees (DICASR).

Die vlugtelingewerk van DICASR het hom egter spoedig betrek by noodsituasies in Afrika, Asië en Latyns-Amerika wat die tradisionele werkgebied van die sending is. ' $n$ Ooreenkoms is bereik met die Internasionale Sendingraad dat DICASR sou konsentreer op vlugtelinge asook korttermyn krisissituasies wat veroorsaak is deur natuurrampe. Spoedig is egter besef dat DICASR hom nie sou kon onthou van hulp by kroniese nood in die lande nie. Dit lei daartoe dat DICASR se betrokkenheid verbreed is tot algemene diakonale hulpverlening. In die lig hiervan word sy naam te Nieu-Delhi in 1961 verander tot Division of Inter-Church Aid, Refugee and World Service (DISARWS). Hiermee het die WRK nou 'n volwaardige instrument vir wêrelddiakonaat tot sy beskikking gehad. DICARWS sou die diakonaat van kerke koördineer en stimuleer en sou ook waar nodig self hulp verleen ${ }^{2}$. Daar is nou aanvaar dat sending en diakonaat noodwendig naas mekaar in dieselfde gebiede sou werk en soms ook sou oorvleuel. Daarom is besluit dat die afdeling vir sending en diakonaat van die WRK in noue oorleg met mekaar moes optree.

Die eerste konsultasie van DICARWS het in 1965 te Genève plaasgevind. Hier is beklemtoon dat die inhoud van diakonia verbreed moet word van diakonaat na sosiale betrokkenheid. Die verskuiwing is van die indiwidu na die gemeenskap en van barmhartighheid na geregtigheid.

Die volgende DICARWS-konsultasie is gehou te Swanwick in 1966 ter voorbereiding van die Uppsala-vergadering van die WRK in 1968. Hier val die klem in 'n groot mate op ontwikkelingshulp en nasiebouprogramme in die nuwe onafhanklike lande van die derde wêreld. Baie aandag is gegee aan die groeiende gaping tussen die wêreld se ryk en arm lande. Daar is bereken dat teen 1990 vyf sesdes van die wêreld se rykdom in die hande sou wees van Westerse kapitalistiese lande. Die konsultasie het bevind dat blote ontwikkelingshulp nie genoeg sou wees om die situasie te verbeter nie. Die kerk sou ook aandag moes gee aan die ekonomiese, politieke en sosiale strukture wat die toestand veroorsaak. Dit sou nie help om net die simptome soos honger, siekte en werkloosheid te behandel nie, maar die werklike oorsaak van die probleem naamlik onregverdige strukture moes aangespreek word.

Die gevolg was dat Uppsala in 1968 'n oproep op kerke gedoen het 
om 'n aansienlike deel van hulle inkomste aan ontwikkelingshulp te bestee. Dit alleen sou egter nie genoeg wees nie. Kerke moes alles in hulle vermoë doen om sosiale en politieke veranderinge te bewerkstellig wat sosiale geregtigheid in wêreldverband sou meebring. Kerke moes werk vir 'n wêreldgemeenskap waarin geregtigheid sou woon. Kerke moes deelneem aan politieke en ekonomiese aksies wat die veranderinge kon meebring. As dit nie op 'n evolusionêre wyse kan geskied nie, kan dit op 'n rewolusionêre manier geskied. Die Uppsala-verslag stel dit soos volg: "In countries where the ruling groups are oppressive or indifferent to the aspiration of the people, and seek to resist all changes by the use of coercive or violent measures, including the 'law and order' which may itself be a form of violence, the revolutionary change may take a violent form ..." (Report of Section III to the Uppsala Assembly, par. 15).

Hierdie besluite het die pad oopgemaak vir die stigting van die Program to combat racism (PCR) in 1969 en die toenemende betrokkenheid van kerke by rewolusionêre verandering van strukture en bevrydings- en selfs terroristebewegings oral in die wêreld. Dit het van kerke politieke en ekonomiese drukgroepe in talle situasies gemaak.

Die groot klem op ontwikkeling sedert Uppsala het uitgeloop op 'n ekumeniese konsultasie oor ontwikkeling te Montreux in 1970. Hier is besef dat die klem minder moet val op die Westerse patrone van industriële en ekonomiese ontwikkeling en meer op die ontwikkeling van die totale mens sodat hy tot beter benutting van al sy menslike vermoëns kan kom. Verder is te Montreux ook besluit om 'n afsonderlike kommissie vir ontwikkelingshulp in die lewe te roep, naamlik die Commission on the Churches' Participation in Develoment (CCPD). Die langtermyn ontwikkelingsprojekte is nou aan CCPD oorgedra. Vir die doel is ' $n$ Ecumenical Development Fund gestig waarvoor kerke gevra is om twee persent van hulle jaarlikse begroting by te dra. Die CCPD sou ook nou skakel met VVO-ontwikkelingsorganisasies.

In 1971 is die WRK se werksaamhede gereorganiseer en is die afdeling "Geregtigheid en Diens" in die lewe geroep waarbinne vier kommissies funksioneer, naamlik CICARWS, CCPD, PCR en die Commission of the Churches on International Affairs (CCIA).

Met die stigting van 'n afsonderlike kommissie vir ontwikkelingshulp is die gevaar groot dat die WRK se diakonale betrokkenheid so verbreed dat dit die wesenskenmerke van kerklike diakonaat verloor en die karakter van algemene humanitêre hulpverlening begin aanneem.

CICARWS omskryf sy taak en doelstellings soos volg: "to assist the churches to manifest their solidarity by sharing their human, material and spiritual resources and to facilitate such sharing so as to promote social justice, human development, relief to human need, including vic- 
tims of disasters, service to refugees and other uprooted people".

CICARWS werk dus soos sy naam aandui op die terreine van interkerklike hulpverlening, vlugtelingehulp en wêrelddiakonaat.

Interkerklike hulpverlening geskied hoofsaaklik deur die Ecumenical Church Loan Fund waaruit lenings met lae rentekoerse aan hulpbehoewende kerke gegee word.

Die afdeling vir vlugtelingehulp konsentreer hoofsaaklik op die miljoene vlugtelinge in Afrika, Asië, die Midde-Ooste en Sentraal-Amerika. In 1983 het WRK-geaffilieerde organisasies meer as 13000 vlugtelinge hervestig en hulp verleen aan miljoene meer.

Onder wêrelddiakonaat ressorteer die afdelings vir trekarbeiders, hulp aan rampgebiede, materiële hulp aan noodlydende gebiede en personeelhulp wat geskied deur die afdeling "Ecumenical sharing of personnel". Laasgenoemde bestaan hoofsaaklik vir die voorsiening van korttermyn personeel vir hulpverlening en ontwikkeling op versoek van kerke in ontwikkelende gebiede ${ }^{3}$.

Die gebiede wat in die jongste tyd die meeste hulp van CICARWS ontvang het, is die droogte-geteisterde lande van Afrika waar in 1984 duisende mense gesterf het van honger en bykans 150 miljoen bedreig is deur ondervoeding. CICARWS het die hulp gekoördineer en binne enkele maande is meer as viermiljoen dollar se hulp in voedsel en kontant deur die WRK na Afrika gekanaliseer").

In 1978 het CICARWS saam met die Ortodokse Kerke 'n konsultasie oor diakonia georganiseer op Kreta. Aangesien hier veral die standpunte van die Ortodokse Kerke na vore gekom het, sal ons dit later behandel.

In November 1986 het CICARWS weer 'n wêreldwye ekumeniese konsultasie oor wêrelddiakonaat gehou te Larnaca op Cyprus. Dit het geskied ter voorbereiding van die sewende algemene vergadering wat beplan word vir 1991 te Canberra in Australië. Hier is beklemtoon dat diakonaat nie geskei kan word van die stryd om geregtigheid en vrede nie. Onderdrukkende strukture wat menseregte benadeel is as sondig bestempel en moet afgebreek en verander word.

Sedert 1978 werk die WRK toenemend met die begrip "Ecumenical sharing of resources". Dit sien op die roeping van kerke om as goeie rentmeesters van God met mekaar die materiële en geestelike gawes van God te deel en so die eenheid en heelheid van die mensdom te help herstel. Larnaca het beklemtoon dat hierdie ekumeniese verdeling van bronne veral op die vlak van plaaslike gemeentes wat mekaar dra en ondersteun, moet geskied. 


\section{Standpunte van die Ortodokse Kerke oor die diakonaat}

In 1978 het CICARWS saam met die Oosterse Ortodokse Kerke 'n konferensie te Kreta gereël met die tema "the Orthodox approach to diaconia". Hier het die Ortodokse Kerke hulle siening van diakonia uitgespel. Dit is gegrond in die offerande van Jesus Christus die groot Hoëpriester. Dit moet daarom verbind word met die nagmaal wat ook universele betekenis het. Daar word opnuut 'n offer gebring vir die geestelike en materiële nood van die hele wêreld. In die diakonaat offer die gelowige homself aan God. Die klem moet nie op materiële hulp val nie, maar op geestelike kwaliteit en ' $n$ ingesteldheid van diensbaarheid. Die uiteindelike doel van diakonia is die redding van die mens en die oorwinning oor die kwaad.

Hiermee het die Ortodokse Kerke ' $n$ belangrike korrektief aangebring op die diakonaat van die WRK wat te veel klem lê op materiële hulp en die verandering van sosiale, ekonomiese en politieke strukture.

Die Ortodokse Kerke het die korrektief duidelik uitgespel: "We look to CICARWS to give greater expression to the spiritual dimension of diaconia: prayer for one another; receptivity to guidance from the Holy Spirit; concern for non-physical suffering and distress; sensitivity to the expression of love in '1, thou, God' relationships" (Report Crete 1978: $12 v)$.

\section{Evangeliese kerke en menslike nood}

Evangeliese kerke was tradisioneel terughoudend om hulle uit te laat oor politieke, ekonomiese, kulturele en sosiale vraagstukke. Dit kon maklik lei tot ' $n$ passiewe aanvaarding van die status quo. Die klem het hier baie sterk geval op die verkondigingstaak van die kerk en die diakonaat was swak ontwikkel en ook beperk tot dade van barmhartigheid.

Hierin het egter geleidelik veranderinge ingetree. In die "Wheaton Declaration" van die evangeliese wêreldkongres van 1966 word 'n oproep op kerke gemaak om standpunt in te neem vir sosiale geregtigheid oral in die wêreld". In die "Declaration of evangelical social concern" van Chicago in 1973 word evangeliese kerke opgeroep om aandag te gee aan die ongelyke verdeling van die wêreld se rykdomme. Hierdie verskuiwing by evangeliese kerke vind duidelik neerslag in die verklaring van die internasionale kongres oor wêreldevangelisasie te Lausanne in 1974 waar dit gestel word: "evangelism and socio-political involvement are both part of our christian duty".

Die internasionale konferensie van evangeliese kerke in Wheaton, 
1983 het in die besonder aandag gegee aan die tema "the church in response to human need". Die uitgangspunt was dat die mees basiese behoefte van die mens is om in gemeenskap met God te leef. Dit het egter konsekwensies vir sy geestelike, fisiese en sosiale bestaan.

Die Wheaton-konferensie verkies om in plek van "ontwikkeling" eerder van "transformasie" te praat. "Ontwikkeling" het te veel die konnotasie van Westerse ekonomiese en tegnologiese strukture wat eenvoudig op alle dele van die wêreld afgedwing moet word. Daarteenoor kan die begrip transformasie van toepassing wees op Westerse en derdewêreldse gemeenskappe. Transformasie word soos volg gedefinieer: "Transformation is the change from a condition of human existence contrary to God's purposes to one in which people are able to enjoy fulness of life in harmony with God"'6).

Transformasie beteken dan dat die menslike samelewing meer in ooreenstemming gebring moet word met die norme van die teenwoordige en komende Koninkryk van God. Dit bring mee dat alle menslike instellings en kulture ook onderwerp moet word aan die koningsheerskappy van Christus. Verder is beklemtoon dat transformasie in die eerste plek moet plaasvind op die vlak van die plaaslike gemeente. Waar wel van interkerklike agentskappe gebruik gemaak word, moet daar gewaak word dat hulle nie groot Westerse magsinstellings word wat hulle eie norme op derde-wêreld gemeenskappe afdwing nie.

Verder word beklemtoon dat transformasie primêr die werk is van Christus deur die Heilige Gees en dat dit nie met geweld afgedwing mag word nie. "We suggest, however, that even under conditions of the most severe repression, such Christians may in fact be challenging society and even be transforming it, through their life-style, their selfless love, their quiet joy, their inner peace and their patient suffering (1 Pet $2: 21-25)^{\prime \prime 7}$.

Dit is duidelik dat die standpunte van die evangeliese kerke in verskeie opsigte belangrike korrektiewe aanbied vir die wyse waarop die WRK sy wêrelddiakonaat beoefen. Die belangrikste is seker die beklemtoning van transformasie deur die krag van die Heilige Gees en die afwysing van geweld. Hier word aanvaar dat selfs geduldige lyding 'n manier kan wees waarop Christene die samelewing kan verander.

\section{Rome, die WRK en sosiale betrokkenheid}

Die Rooms-Katolieke Kerk met twee keer soveel lidmate as die 305 lidkerke van die WRK het nog altyd daarin volhard om sy eie sending, ekumeniese en diakonale strukture in stand te hou onder die sentrale beheer van die Vatikaan. Inskakeling by die WRK is om dié rede vir die 
RKK nie denkbaar nie. Die RKK het sy eie wêrelddiakonaat ontplooi deur die "Catholic Relief Services" waarop ons nie breedvoerig sal kan ingaan nie. Die sosiale betrokkenheid van die RKK staan onder beheer van die "Pontificial Commission on Justice and Peace".

Na Vaticanum II se besluite kon daar nouer skakeling plaasvind tussen die WRK en die RKK. Dit lei tot die stigting van die Joint Working Group in 1965 wat die skakeling tussen die twee kerke behartig. Dit het die pad oopgemaak vir 'n ondersoek na moontlike samewerking op die terrein van sosiale betrokkenheid. In 1967 is die "Committee on Society, Development and Peace" (Sodepax) gekonstitueer as 'n gesamentlike kommissie van die WRK en die RKK. Die wêrelddiakonaat en sosiale betrokkenheid van die RKK het egter in so 'n mate sy eie selfstandige koers opgegaan dat daar nie werklik van grootskaalse samewerking sprake was nie. Die gevolg was dat Sodepax in 1981 ontbind is en vervang is met ' $n$ "Consultative Group on Social Thought and Action". Dit is bloot 'n forum vir die diskussie van sosiale vraagstukke en nie ' $n$ orgaan vir samewerking nie.

\section{Die Ned Geref Kerk en wêrelddiakonaat}

Die grootskaalse betrokkenheid van kerke by wêrelddiakonaat verplig die Ned Geref Kerk om sy eie diakonale strukture weer in oënskou te neem. Die diakonaat van die Ned Geref Kerk is sterk na binne gerig en ontbreek in 'n groot mate aan missionêre en mondiale dimensies. Dit behoort reggestel te word.

In die proses moet daar egter deeglik gekyk word na die slaggate van wêrelddiakonaat en moet daar geleer word uit die ervaring van ander. Die geskiedenis van die wêrelddiakonaat van die WRK en die korrektiewe wat die Ortodokse en Evangeliese kerke daarop aangebring het, kan hierin van groot waarde wees.

Die Ned Geref Kerk met sy beperkte middele moet vir homself duidelike prioriteite stel. As 'n kerk wat leef te midde van die nood in Afrika, sal hy sy eerste prioriteit seker in Afrika moet soek. Daar moet groot versigtigheid aan die dag gelê word om groot en duur strukture te vermy. Veral die diakonaat van die plaaslike gemeentes moet meer na buite gekeer word en wêreld diakonaat moet ook daar sy wortels vind.

Ten slotte is daar ' $n$ aantal belangrike knelvrae rondom wêrelddiakonaat wat eers deeglik in ag geneem sal moet word voordat enige kerk dit kan waag om hom te begeef in hierdie riskante onderneming.

\section{Enkele knelvrae rondom wêrelddiakonaat}

Enige kerk wat ernstig betrokke wil raak by wêrelddiakonaat sal eers ern- 
stig aandag moet gee aan 'n aantal knelvrae. Ek wil 'n paar hiervan slegs aanstip sonder om oplossings te probeer kry.

\subsection{Afgrensing van die diakonaat}

Ons het gesien dat die WRK se diakonale betrokkenheid al hoe breër geword het totdat dit samewerking met Islam, Buddhisme, Hindoeisme en Judaïsme ingesluit het en ook rewolusionêre verandering van strukture goedgekeur het. Dit bring die vraag na die afgrensing van die diakonaat na vore. Die onderskeidingskenmerke van christelike diakonaat sal duidelik uitgespel en afgegrens moet word. Dit mag nooit so bedryf word dat dit die kerk se roeping tot evangelisering en sending vervang nie.

\subsection{Diakonaat en die plaaslike gemeente}

Dit bly 'n groot vraag en 'n worsteling hoe om wêrelddiakonaat terug te koppel en sy oorsprong te laat vind in die plaaslike gemeente. Dit word te veel bedryf deur groot kerklike organisasies wat weinig kontak het met plaaslike gemeentes. Diakonieë en gemeentelede moet direk daarby betrek word.

\subsection{Diakonaat en strukture}

Die vraag van diakonale strukture moet deeglik oordink word. Hoe moet gemeentes ingeskakel en verteenwoordig word op breëre strukture? Hoe moet sending en diakonaat met mekaar skakel? Hoe moet interkerklike en ekumeniese strukture daar uitsien? Hoe kan voorkom word dat strukture so lomp en duur word dat 'n groot deel van die organisasie en fondse in die bedryf daarvan bestee moet word eerder as aan werklike hulpverlening en nood? Organisasies vir wêrelddiakonaat dreig oral om burokrasieë te word met magsbasisse wat nie maklik prysgegee word nie en wat maklik onder kerklike beheer uitbeweeg.

\subsection{Die vraag van personeelvoorsiening}

Oral in die wêreld word baie aandag gegee aan personeelvoorsiening vir diens in ontwikkelende gebiede. ' $n$ Mens dink aan die Peace Corps van Amerika, die organisasie Dienste in Übersee van Wes Duitsland en Dienst over Grenzen in Nederland. Die getal korttermyn werkkragte wat by diakonale en ontwikkelingsprojekte betrokke is, het dramaties toegeneem. Die vraag ontstaan of ons nie ook in Suid-Afrika 'n behoefte 
het aan gekoördineerde en beplande werwing en plasing van personeel wat kan help met noodlenigings- en ontwikkelingsprojekte in Afrika en elders in die wêreld nie.

\subsection{Die vraag van samewerking met humanitêre organisasies, die staat en politieke groeperinge}

Naas die kerk is buite-kerklike humanitêre organisasies soos World Vision, Operation Hunger en talle ander ook besig met verdienstelike werk. Ook die staat is besig met omvangryke noodlenigings-, arbeidsverskaffings- en ontwikkelingsprojekte. Die kerk sal vir homself die voor- en nadele van samewerking met die instansies moet uitmaak. Die vraag sal gestel moet word of deelname aan politieke diakonaat nie die kerk sal dwing om kant te kies in politieke konfliksituasies nie? Dit kan lei tot nog groter polarisasie.

\subsection{Die vraag na die doelstellings met wêrelddiakonaat}

Die kerk sal die Bybelse en teologiese grondslae van wêrelddiakonaat duidelik moet uitspel en van daaruit sy doelwitte omlyn. Wat wil hy daarmee bereik? Kan dit nie 'n bodemlose put word waarin skaars kerklike bronne eenvoudig verdwyn nie? Daar moet gewaak word dat woord en daad, en materiële en geestelike aspekte nie van mekaar losgemaak word nie. Diakonaat moet steeds bedryf word binne die raamwerk van die Koninkryk en wel as die oprigting van die tekens daarvan. Voordat met die praktyk van wêrelddiakonaat begin kan word sal die teologie daarvan dus eers duidelik uitgespel moet word.

Uit bogenoemde is dit duidelik dat ekumeniese, missionêre en wêrelddiakonaat 'n omvangryke aksie van die kerk in die wêreld van ons dag geword het. Dit is verder duidelik dat die NGK ernstig aandag sal moet gee aan sy eie betrokkenheid daarby. Enige betrokkenheid daarby sal egter voorafgegaan moet word deur ernstige studie, navorsing en teologiese besinning.

Met die veelvoudige vorme van nood in Afrika is die tyd egter ryp vir die NGK om 'n begin te maak met die proses.

\section{NOTAS}

1. D Crafford, Wêre/dsending en wêrelddiakonaat (ongepubliseerde proefskrif), Pretoria 1966, 2 e.v.

2. D Crafford, Die sosiale betrokkenheid van die kerk in die sending, ekumene en praktyk, Pretoria 1978, 25 e.v. 
3. Word Council of Churches: One World no 102 (Jan Febr 1985), 30-32.

4. Ibid., 32

5. "Wheaton Declaration", International Review of Mission", vol LV (1966), 458.

6. RES Mission Bulletin, The Church in Response to human need, vol III/4, (1983), 5

7. lbid., 5. 